\title{
Real Estate Brokers: Do they inflate housing prices? \\ The case of France
}

\author{
Wendy Violand \\ Arnaud Simon ${ }^{1}$ \\ Université Paris Dauphine \\ CEREG \\ Place du Maréchal de Lattre-de-Tassigny \\ 75775 Paris Cedex 16
}

${ }^{1}$ Contact author : arnaud.simon@dauphine.fr 


\section{Real Estate Brokers: Do they inflate housing prices? \\ The case of France}

Abstract: This study examines the impact of real estate brokers on the price of residential properties sold in 2005 in twelve French cities. The results indicate that brokers increase the prices of properties they sell even though they appear to have heterogeneous behaviours across cities. The impact of brokers also varies by property size and age of clients. One and two room apartments have higher selling prices when sold through brokers. Buyers in their thirties and forties who seek the assistance of brokers pay more for their homes whereas older sellers obtain higher prices from broker intermediation.

Key words: residential real estate market, broker intermediation, brokers' effect on price 


\section{Introduction}

Housing expenditures represent a large part of household spending and is a major economic indicator in industrialized economies. As the real estate brokerage industry plays an important role in the residential market, it is worth analyzing the impact of this industry on the sale price of houses. The present paper examines the effect of real estate intermediation on sale price in the French residential market.

A recent national survey ${ }^{2}$ conducted by the Direction générale de la concurrence, de la consommation et de la répression des fraudes - which is the French agency in charge of ensuring fair trade and competition - found evidence of numerous offences in the real estate brokerage industry. Out of the 1070 real estate agencies that were inspected, $830(77.6 \%)$ were in violation of the law. The main infractions concerned misleading advertising, absence of commission displays in the agencies, absence of professional ID card, and real estate agents' operating without mandate from owners. The impact of real estate agents on housing prices is an important issue as, along with the frauds recorded in the survey, it may potentially trigger legislative changes in the real estate brokerage industry.

Home sellers may either try to sell their house on their own or seek the assistance of professionals. The real estate broker is one of these professionals (notaries may also act as broker in France, however they do not enter in the field of the present study; we will focus only on real estate brokers). A seller, marketing his house without intermediation of real estate brokers, bears the cost of searching for buyers and the cost of showing the house. Similarly, home buyers face the costs of gathering information. These costs are borne by real estate brokers when involved in the transaction. Indeed the main role of the real estate broker is to match the level of housing desired by buyers with houses proposed for sale. In order to

\footnotetext{
${ }^{2}$ Published in the review Concurrence \& Consommation, $\mathrm{n}^{\circ}$ 154, July-August-September 2007.
} 
accomplish this task, they collect information about both buyers and sellers, and house characteristics. Under French $\mathrm{law}^{3}$, the real estate agent has the obligation to inform and advise both the buyer and the seller, guarantee the reliability of the transaction, facilitate the bargaining process, and carry through the transaction. For all these services, the broker charges a fee which, depending on the real estate brokerage contract, can be either at the seller's expenses, the buyer's expenses or shared between the two. Generally the commission paid to the broker is a percentage of the sale price which is displayed in the agency but can be negotiated. Brokers have the incentive to sell at the highest price in order to withdraw a higher cash commission but this may be washed out by timely marketing costs and competitive pressure from direct negotiation between buyers and sellers. In the opposite direction we have to mention the popular belief, widespread among the real estate brokers in France, that consists in asserting that individuals who sell their good by themselves tend to increase the house price. The broker's job is then to bring back the prices to their market level, convincing the seller to decrease its price. But, is this a real social justification of the usefulness of the brokers, or just a commercial argument? As we can see, the price impact of the brokers is not necessarily obvious at first glance; one of the aims of this article is to disentangle the situation and to study the sign of this impact.

The empirical literature provides conflicting evidence on the impact of real estate intermediation on housing prices. It is presumably due to differences in statistical methods, small sample sizes and geographically concentrated data. Moreover, most studies have focused on American data and none have, to our knowledge, examined the effect of brokers on prices in the French residential market. In this paper we estimate the effect of real estate brokers on housing prices using a large set of transactions realised in 2005 from twelve French cities dispersed nationwide ${ }^{4}$. The database includes home sales performed with and

\footnotetext{
${ }^{3}$ Hoguet act of January 2, 1970

${ }^{4}$ The city of Paris is not included in this study because the information concerning the presence or not of a broker in the transaction was not available.
} 
without the assistance of a broker. We model housing prices as a function of house characteristics according to the classical hedonic approach and whether or not a real estate broker takes part in the transaction.

The results of the study indicate that real estate agents increase housing prices by on average $1.3 \%$. But they seem to have heterogeneous behaviours across cities. In particular, the level of influence of real estate brokers on housing prices is not homogenous across cities and not always significant. Brokers tend to influence the price of small accommodations. Furthermore, men have a higher probability of buying through a broker and brokers appear to increase the selling price of houses bought and sold by single men. Buyers under forty and sellers under thirty years old who presumably lack experience in the real estate market are more likely to seek the assistance of a broker. Buyers fifty years old tend to pay more for their homes whereas older sellers obtain higher prices when using a broker.

Section 2 reviews the literature on the effect of real estate intermediation on house prices and search duration. The French real estate brokerage industry is described in section 3 . The data and methodology are presented in section 4. Section 5 contains the empirical results and the final section presents the conclusions of the study.

\section{Literature Review}

The literature on the determinants of housing prices including traditional estimates of housing demand, hedonic modeling of housing prices, models of the search and bargaining processes is extensive. However, few researchers have studied the direct effects of real estate agency representation on the housing market and in particular on home selling prices. Conflicting results have risen from empirical studies on this important topic. Some conclude that real estate brokers do influence the selling prices of homes, others refute such effect. Moreover, results also differ across house price ranges. The lack of consensus in the literature may 
reflect the fact that the data used was too local and sample sizes relatively small. In addition, early empirical results were not systematically corrected for selection bias in the samples. Indeed, Jud, Elder, Zumpano and Baryla, among others, have shown that buyers who buy through a broker have different characteristics and different housing consumption level than those who search by themselves.

Jud (1983) estimated the demand for real estate brokerage services by both sellers and buyers using a conditional Logit model. The results obtained from 529 housing transaction data in 1979 from three urban areas in North Carolina indicated that home sellers' decision to engage a real estate broker mainly depends on housing market transaction costs including the cost of seller's time. For home buyers, Jud found that the decision to use a broker during housing search was determined by the buyer's prior knowledge of the housing market and the opportunity cost of the buyer's time. Jud measured the buyer's information level on the housing market by identifying whether or not the buyer was a local resident, familiar with the market and whether or not the buyer was an experienced previous owner. It appeared that higher income buyers were more likely to employ a broker. Buyers who seek the assistance of brokers conducted more rapid searches and spend substantially more on housing. Jud found that brokers do not influence the prices of the houses they sell, although they do increase the level of housing consumption of buyers.

In a subsequent paper, Jud and Frew (1986), using different data (one single area in North Carolina) and methods, found that broker-assisted home sellers obtain higher prices for their homes. They confirmed the previous conclusion that broker-assisted home buyers have higher demands for housing than buyers who do not employ real estate agents. They suggested that broker intermediation generates sales effect similar to that of advertising. Indeed, brokers play a screening role for sellers by matching up potential buyers whose demand for housing corresponds to the houses of the sellers they represent. 
Black and Nourse (1995) examined the effect of two brokerage modes on both price and closing cost allocations between buyers and sellers based on only 80 single-family residential sales between early 1989 to mid-1990 in north suburban Atlanta, Georgia. The first model, the seller-only representation, corresponded to the situation where the seller is represented either by a listing broker only or, by a selling broker acting as a subagent to the listing broker. The second involved buyers represented by buyers' broker, the sellers being either represented by listing broker or unrepresented. They demonstrated that buyers' broker managed to shift a substantial portion of closing costs to the seller. This shift was most pronounced above a low level of house prices, at which the seller absorbs most closing costs regardless of the mode of brokerage. Employing a hedonic pricing model, they found no significant impact on home prices based on the brokerage mode used in the transaction. This means that buyers do not obtain lower prices by hiring buyers' agent.

Bajtelsmit and Worzala (1997) applied legal and economic theory of agency to anticipate the impact of adversarial brokerage and separate buyer representation on transaction prices, on both buyer's and seller's net gain relative to their reservation price, and on commission fee paid to brokers. They compared the theoretical bargaining outcomes among transactions with no brokers, with one broker representing the seller under an exclusive right-to-sell contract, with two brokers and the buyer informed that the second broker is a subagent also working on behalf of the seller, with two brokers and the buyer unaware of the sub agency situation, and with two agents and the buyer being represented by a buyer broker. Commission fees were set as a percentage of the transaction price.

The theoretical results of Bajtelsmit and Worzala (1997) indicated that the no-broker case yields the lowest sale price and largest net benefits to the buyer and the seller. The transactions which involved a single broker and two brokers with disclosed agency are found to result in higher prices and lower net gains but still an equitable split between the buyer and 
the seller. The situation in which two agents do not disclose agency relation to the buyer, the model anticipated the highest sale price, seller net benefit superior to the one obtained in the two previous scenarios, and a zero net benefit to the buyer. The latter case is unfavourable to the buyer as he mistakenly believes that the subagent is his representative and therefore may reveal confidential information such as reservation price. Finally, buyer brokerage and agency disclosed to the seller with percentage commissions and equal bargaining power yielded the same sale price as in the no-broker case but a lower equitable net benefit. All the agency arrangements considered lowers the seller's net proceeds and increases the buyer's net costs than the no-broker case. However, brokerage services enable to reduce search time and administrative tasks which are not accounted for in the authors' theoretical model.

Zumpano, Elder and Baryla (1996), using a Heckman two-stage model and 2,495 crosssectional observations from the United-States in 1986, examined the decision to use a real estate broker and the effect this decision has on house prices. The estimated results suggested that buyers with high opportunity $\operatorname{costs}^{5}$ and the least amount of information about local housing market conditions were more likely to engage a real estate broker. They found presence of selection bias as buyers who use brokers tend to purchase more expensive homes. In a subsequent study, Elder, Zumpano and Baryla (2000), using a smaller dataset of home transactions (from 558 to almost 900) carried out in the latter part of 1995 from over 600 counties in the US, tested for the impact of buyer brokers on selling price and search duration by examining different type of brokerage intermediation. It appears that higher income buyers are more likely to seek the assistance of a buyer's agent, as are those with more information and experience of the housing market. They show that real estate brokers have no independent effect on home prices, regardless of the type of broker. However, brokers and especially buyer brokers do manage to reduce buyers' search time.

\footnotetext{
${ }^{5}$ Annual income is used as a proxy for opportunity costs.
} 
Benjamin and Chinloy (2000), using a sample of 176 single-family houses from two neighbourhoods in northwest Washington sold in 1992, examined the use of buyers' broker through two alternative house marketing strategies. The pricing strategy adopted by motivated sellers who set their listing price at or below market price in hopes of a timely sale. Alternatively, the exposure strategy consist of setting the listing price above the market price, and increasing advertising and brokers' effort in order to obtain a higher final price. They found a positive relation between buyer brokerage and increasing listing prices. The authors conclude that sellers' brokers concentrated their time on sellers following the pricing strategy. In the case of the exposure strategy, sellers' brokers spend less effort on searching for buyers and, therefore, are more inclined to accept to split their commission with a buyer broker who brings in a client.

Zietz and Newsome (2001), examined whether and to what extend the buyer's agent commission rate affected transaction prices using a data set of 592 house sales from Orem, Utah, from 1990 to 1997 . They found that higher commission rate led to higher sale price only for houses at the lower end of the market. The coefficient calculated from higher priced houses was positive, but not significant. They suggested that buyers of higher priced houses are more experienced in dealing with real estate brokers and are, therefore, less likely to be influenced by them. Alternatively, they postulated that the higher commission on lower-priced homes provided a minimum dollar amount under which the buyer broker would not bore the cost of spending time searching for potential buyers.

Zietz and Newsome (2002) used a larger sample of 1334 house transactions in Orem from mid-1999 to mid-2000 to examine the impact on price of the type of agent representation. They found that unrepresented buyers of small-to-medium-sized houses paid on average $2 \%$ more for their houses than buyers who were represented by buyers' agent. However, for these types of houses, raising the commission percentage paid to the buyer's agent raised price. 
Therefore, redistribution of the commission toward buyer's agent may completely offset the price advantage obtained from hiring a buyer's agent. Smaller and larger houses showed no statistically significant coefficients with respect to buyer's agency. Buyers of medium-to-large houses represented by a buyer's agent from the same firm as the listing agent get a better deal for their homes.

Evans and Kolbe (2005) used a repeated-sale price index model to examine the effect of agency choice on the profit made by owners when re-selling their homes. Based on over 4,000 repeat sales between late 1997 and early 2003 in Memphis, Tennessee, they first showed that dual agency, which involves one agent representing both buyer and seller, had no compelling impact on expected gain or on heteroskedasticity. This supports the fact that dual agency does not generate a systematic bias in favour of either buyers or sellers nor are there large effects of agent misrepresentation. They, then, found that homeowners employing the agent who sold them the house as the listing agent upon resale is a major source of heteroskedasticity and is associated with increased price gains over the tenure period.

\section{The French Real Estate Brokerage Industry}

The real estate agent is an intermediary involved in the transactions of purchase, sale, exchange, subletting or rent of houses, apartments, businesses, grounds. He represents one of the parties which can be the buyer, the seller, the owner or the tenant. In France, the ethics of real estate activities is defined by the Hoguet act of January 2, 1970. It has been modified by the Edict of July 1, 2004.

An individual who wishes to sell his house may seek the assistance of a real estate broker. In this case, a real estate brokerage contract signed between both parties is compulsory in order to give mandate to the real estate agent to start searching for a buyer. The real estate brokerage contract indicates the mission of the real estate agent, the description of the house 
to be sold, the expiration date of the contract, the price wished by the seller for his house, the amount of the financial compensation due to the agent, and who of the seller or the buyer pays the commission. The financial compensation can be flat or a percentage on the selling price generally set from 5 to $10 \%$. It is usually paid by the buyer as it is added to the selling price of the house. The percentage of the commission varies according to the price of the house. Generally the higher the selling price, the lower the commission. The real estate agents are free to choose the fees they charge but they have the obligation to display them in the agency. Naturally the client may negotiate the fees with the broker. Moreover, even if real estate agencies often get along to apply similar commissions, during the negotiation process, the buyer may put the agencies in competition to obtain a lower commission and hence a lower selling price.

The real estate agent has the obligation to inform and advice not only the principal, but also all the prospective buyers. He also has to facilitate the bargaining process and complete the transaction. The agent has to give a true valuation of the house to the seller.

The real estate agent operates with a license renewable annually. Since January 2006, three types of professional ID cards exist: transactions on buildings and business, real estate management, and listing agents. To obtain the professional ID card, the applicant has to fill in the following conditions:

- In terms of education he must hold either a two year degree after high school in the field of real estate or, a three year degree in the areas of legal, economic or commercial studies. If the applicant does not hold any of these diplomas, he must attest of a professional experience in the real estate sector either of at least three years if he has the high school diploma or an equivalent diploma, or of at least ten years if he has none of these diplomas (reduced to four years in the case of an executive position); 
- Have a financial guarantee which must be at least equal to the maximum amount of funds he will hold;

- Obtain a certificate from the register of the Chamber of Commerce;

- Subscribe to civil liability insurance.

- Have an attestation delivered by his bank specifying the account number on which the client's money will be deposited

- He must have never been condemned for an offence quoted in the Hoguet law.

Thus, it is fairly easy to obtain a real estate agent ID card. It is even easier to obtain a salesperson license (grey card). The only requirement is to never have been condemned for the same offences than those required for real estate agents. The salesperson generally employed by a real estate agency is in charge of matching buyers and sellers. His job also consists of routine tasks such as placing signs on properties, posting advertisement in newspaper, on the Internet, or in the agency, and updating client files. The salesperson receives a commission on the sales which is specified in his employment contract and can vary according to his status (employee or independent negotiator).

The real estate brokerage industry is attractive to entrepreneurs who hope to earn money fast. There are no stocks to manage, the initial investment is small, and salespersons are paid on their performance. Therefore the turn over is significant and every day new agencies open hoping to take advantage of this situation. A quick glance in the Yellow Pages (dated as of September 2007) reveals that, in Paris, one can find 629 flower shops, 753 banks, 872 bakeries, 2,326 "cafés", and 3,191 real estate agencies. This can also be observed in other French cities.

Baker (2007) examines the ethics of legal standards that limit entry into the American real estate brokerage industry. He finds that raising educational requirements increases the average commissions, without improving the quality of brokerage services. In France, as the 
educational and experience standards for real estate brokers are fairly low, it encourages high competition between brokers especially these last years since prices in the real estate market have risen considerably. Moreover, competition with the for-sale-by-owner market is fierce; $40 \%$ of real estate transactions are concluded without the intermediation of a real estate broker. Concerning the remaining $60 \%$, real estate agents have to compete against notary and listing agents. In spite of the high level of competition in the real estate market, the commissions applied by brokers are persistently high.

\section{Data and Methodology}

\section{Data}

The study uses residential real estate data from the PERVAL database. PERVAL gathers information on real estate transactions outside Paris region collected by notaries at the time of the sale. The data totaled 10,610 residential apartment transactions from twelve cities in France (including neighborhood distinction in Lyon and Marseille ${ }^{6}$ ) realized in 2005. The data set included assisted $(7,495)$ and non-assisted $(3,115)$ home sales, housing characteristics and information on both buyers and sellers. Assisted transactions are concluded with the intermediation of real estate agents or real estate developers.

\section{Methodology}

We aim to examine the effect of real estate brokers on housing prices in comparison with prices obtained by owners selling their own houses. Buyers' and sellers' have the choice between undertaking their search alone or with the assistance of a real estate broker. As previous researches have shown, the decision to use a broker and the price paid by buyers are the two sides of the problem.

\footnotetext{
${ }^{6}$ For Marseille there are seventeen categorical variables: one for each sixteen districts and one that gathers all the transactions that lack information on the district. We kept the latter variable as even though there is no precision on the location these transactions bring valuable information.
} 
We model the choice to use a broker by estimating two Probit equations. The dependent variable is the dummy variable RE which is equal to one if a real estate broker is used in the transaction and zero otherwise. In the first equation, RE is explained with the classical hedonic variables (physical characteristics mainly). In the second equation, we explain RE with the buyers' and sellers' characteristics.

We then estimate whether or not real estate brokers affect the prices of transactions. We regress the selling price per square meters (PM2) on the hedonic variables and the presence or not of a real estate broker. PM2 is always a gross price which does not include the broker's commission. We then practice regressions on subsamples as housing characteristics do not necessarily have a unique price across the full sample due to heterogeneous individual preferences. In particular, when individuals have different preferences for housing features, individuals may pay different prices for these features even though the hedonic price surface is the same. We construct subsamples according to independent housing and individual variables.

\section{Variables}

The city location is used as a measure of real estate brokerage implantation or area habits. It may turn out that, in some cities, the real estate brokerage industry is more active than in others. Moreover brokers from different cities may not have homogenous behaviours and thus not affect prices the same way. The period of construction is employed to control for age in the real estate markets. Indeed, the value of buildings depends on the construction period, as some periods may be more prestigious than others and therefore more demanded. For example, old styles such as art nouveau (1890-1914) and art deco (1920-1939) that fall respectively in the second and third categories are much-sought. On the contrary, buildings constructed after World War II in response to the housing shortage crisis are less valued. The age variable is also a proxy for the obsolescence. Another point concerns the "loi 
Robien" which was passed in 2003, in response to the housing shortage crisis, to stimulate real estate investment in order to face rental demand and to boost the real estate construction market. The Robien law concerns new accommodations rented as main homes and for a minimum of 9 years. The rents are blocked under an upper limit according to the geographical location. It enables real estate investors to lower their income-tax while building up a real estate holding. Indeed, investors can deduct $6 \%$ of the price during the first seven years and 4\% during the following two years. Moreover, the rents benefit from $6 \%$ abatement. Ultimately, with this law, an investor can deduct up to $65 \%$ of the amount invested. The law did increase investment in the new housing market and especially for small accommodations. The number of rooms is included to control for the fact that the bigger the apartment, the smaller the price per square meter. Also, small accommodations are more frequent and are more demanded in cities than big apartments which can be found usually in the suburbs.

The decision to use a broker may also depend on the type of apartment. Duplexes and triplexes may be harder to sell than standard goods and therefore brokers may be more successful in matching buyers and sellers. We control this phenomenon with the variables Standard, Loft, Duplex and Triplex.

The month in which the closing of sale occurred is included to account for price variations in the real estate market. Estimations reveal that there is an increasing trend of prices through the calendar year although the first months of the year are not always significant. For more details see annex 1.

The socio-occupational categories developed by the National Institute of Statistics and Economic Studies (Institut National de la Statistique et des Études Économiques: INSEE) for coding the population census is employed as a measure of opportunity cost of search. Even though, there are only eight categories, it gives indication on income levels and social characteristics. People from the socio-occupational categories Managers and higher-grade 
occupations, Intermediate-grade occupations, Clerical workers, and Manual workers are predominant in the buyers' population and a little bit less present in the sellers' group. On the contrary, the retired category is more active on the sell-side than on the buy-side. It is well known in the literature that real estate broker reduces the search duration of their clients. Hence, higher social categories, with presumably higher opportunity costs, will probably choose to engage a real estate broker.

Other characteristics such as matrimonial status, age, or nationality may also affect the decision to engage a real estate broker. Nationality is included to assess informational advantages on the real estate market that French people may have relatively to foreigners. Individuals with less knowledge of the market may have a greater incentive to seek the assistance of a broker. Moreover, buyers coming from countries with expensive housing could spend more for their houses in the destination city. Simonsohn and Loewenstein (2006) find that households moving from more expensive cities spend more in rent in their new city than those coming from cheaper cities, holding other factors constant. They also show that as people stay in their new city, they get used to the new prices and readjust their housing expenditures.

Finally, the variable RE indicates whether and to what extent real estate brokers affect the sale price of houses they sell. A positive significant coefficient would suggest that real estate brokers do increase the price of houses they sell. A complete description of the variables used in this study can be found in Table 1. Summary statistics are displayed in Tables $2 \mathrm{a}$ and $2 \mathrm{~b}$. The first three columns show statistics for the broker-assisted, the non-broker-assisted, and the full sample respectively. The last column gives, for each variable, the proportion of broker-assisted transactions in the full sample. 


\section{Empirical Results}

\section{The Probit Models}

The Probit estimates of the decision to use a broker are found in Tables 3 and 4 . The omitted categories for each characteristic define a base; the intercept is associated to the probability for this initial situation. The dummy variable coefficients for the remaining categories measure the extent to which the probability to use a broker differ from the base. Buyers falling into the socio-occupational categories artisans, shopkeepers, and employers, and other persons without occupational activity are more inclined to use a real estate broker.

For the artisans we may consider that their purchase is sometimes not purely residential. It is quite frequent to have the shop at the ground floor and the apartment at the first floor. The commercial side of the trade is maybe the reason why a broker is used more frequently. But this result could also be interpreted as an opportunity cost problem. Indeed, these categories have usually some strong time constraints due to their job. The latter category of course includes unemployed individuals searching for jobs but not only. It may also include housewives, house husbands, heirs, retired persons too young to fall into the retired category... We assume that people who have money problems do not purchase houses. Hence, buyers who fall into this category are assumed to be wealthy and therefore are maybe more willing to pay for the services of real estate brokers. None of the socio-occupational coefficients for sellers are significant.

Buyers in their thirties are statistically more likely to use a broker in their search but the coefficient is very small. These buyers may lack of time as they usually have early-aged children which are time consuming. Moreover, these young buyers may be first time owners and therefore, have less knowledge on the real estate market than more experienced buyers. Indeed, it may be their first time buying a house. Sellers aged between thirty and seventy nine years have lower probabilities of seeking the assistance of a broker. This is especially true for 
sellers in their fifties, sixties, and seventies. These sellers may have some experience of the real estate market as they may already have sold a house previously. Moreover, as all the coefficients of sellers' age variables are negative this means that the omitted category, which corresponds to sellers between 18 and 29 years old, tend to use brokers while trying to sell their apartment (the percentage of the sellers in this category is $6.8 \%$ ) .

Divorced women tend to search for houses on their own. In France, women usually obtain custody and, even though they receive alimony, part of the household revenue is lost following the divorce. So, with less money, they would try to find approximately the same type of apartment than the one they used to live in before the divorce and therefore save the commission due to the broker. On the contrary, divorced men are more likely to employ a real estate broker to help them find a home. Women under a PACS (Pacte Civil de Solidarité) contract tend to search without the assistance of a broker. The coefficient is quite strong and significant at about an $8 \%$ level. On the contrary, the coefficient for men who have the same status is not at all significant. The PACS created in 1999 is bounded to homosexual couples who cannot legally get married but wish to have a status closed to the one of married couples or to couples who wish to benefit from financial, patrimonial and fiscal advantages without getting married. Unfortunately, the proportion of woman-woman, woman-man, and man-man PACS are not known as this information is for now considered confidential and therefore not registered. Nevertheless if we assume that most PACS contracts in the category PACS_women are concluded between two women then the presence of male buyers seem to increase the probability of engaging an agent globally. Indeed, disregarding the significance level we note that single women, divorced women, women under a PACS contract, and widows tend to search for a house without the assistance of a broker. While all the coefficients of matrimonial status for men buyers (except for widowers), and the coefficient corresponding to married or remarried women (necessarily to a man) are positive. This result 
is very interesting as it reveals that men and women have different preferences with regard to the way they lead their housing search. The coefficients of sellers' matrimonial status, although not significant, lead to the same observations with some exceptions (single and remarried women).

The nationality coefficients for both buyers and sellers are not significant in general with two exceptions for buyers: Spain and United Kingdom. This can be explained by the fact that some British and Spanish brokers are specialized in the French residential real estate market. British and Spanish people who wish to buy an apartment in France may then seek the assistance of brokers who are not licensed by the French government and therefore can not be registered in the Perval database as taking part of the transaction. Note that, concerning buyers, all European nationality coefficients are negative whereas the ones of the remaining nationalities are positive with the exception of the other nationality category. This is not true though for sellers' nationality.

The period of construction enables to control for apartments in prestigious buildings and obsolescence. The period $\mathrm{H}$ includes new homes and resale of homes constructed since less than five years. The coefficient for this variable is negative and highly significant. Buildings constructed between 1992 and 1999 (period G) have also less probability to be sold with the assistance of agents. This is surprising as the assisted category does not only include real estate agents but also real estate developers and estate agents. Summary statistics reveal that there is a larger share of apartments constructed under these two periods in the professional assisted sample than in the non-assisted sample. Moreover, $76.9 \%$ and $78.3 \%$ of apartments falling into $\mathrm{G}$ and $\mathrm{H}$ respectively where sold through brokers.

Triplexes have a high probability of being sold by real estate brokers even though summary statistics indicate that only $52.4 \%$ of triplexes in the database where sold through brokers, which corresponds to the smallest proportion of real estate intermediation. This can be 
explained by the fact that in the probit equation we control for other characteristics. There are not many buyers seeking for this type of apartment therefore sellers may turn to brokers for help. Moreover, buyers searching for triplexes may have high opportunity costs and thus engage a broker to reduce search time. The coefficients for lofts and duplexes are not significant.

Concerning the number of rooms, only five-room houses have a significant coefficient which is negative but at an $8 \%$ level. Five-room homes are mainly sought for by large families who may have a high budget constraint and therefore search on their own to save the commission due to brokers. Although the other coefficients for houses with 3 to 8 rooms are not statistically significant, they are negative. This result suggests that single-room accommodations are more likely to be sold by brokers.

Houses in the fourth, eighth, fourteenth, and fifteenth districts of Marseille have a higher probability of being sold through a broker. See the map of Marseille segmented by districts in annex 2. The seven first districts builds-up the town center around the vieux port. The fourth district is a little off-centered compare to the other six districts. We may suppose that buyers searching for apartments in the town center may not explore this district therefore sellers may seek the assistance of brokers in order to bring prospective buyers into this area. Concerning the out of center districts the eighth district is the most expensive whereas the fourteenth and fifteenth districts have some red-light areas. Apartments situated in Lille and Tourcoing, two cities in the North of France, are less likely to be marketed by brokers. The remaining coefficients for location are far from being significant. The summary statistics in Table 2a indicate that Marseille, Lille-Roubaix-Tourcoing, and Nantes are not homogeneous between the broker and the non-broker assisted transactions samples. Marseille has the smallest percentage of real estate broker intermediation. Furthermore, a larger part of the non-broker assisted sample concerns transactions in Marseille compared to the broker assisted sample. 
The opposite is true for Lille-Roubaix-Tourcoing and Nantes. The differences between the summary statistics and the probit results indicate that, in these cities, there may be some underlying characteristics that strongly impact the presence or absence of brokers in the transactions.

\section{Regressions}

Several regressions of the selling price were performed. The R-squares are in majority around 0.40 and the adjusted R-squares are about 0.33 . We first estimate a regression on the full sample by controlling for difference in housing characteristics, and included the dummy variable $\mathrm{RE}$ which indicates the presence or the absence of a real estate broker in the transaction. We then model the selling price for various subsamples constructed using hedonic and individual characteristics. The variable of interest is of course RE as we wish to examine the impact of real estate brokers on the selling price of houses. The values and the significance levels of the coefficient RE for the full dataset and the subsambles can be found in Table 5. Note that even though not all coefficients are significant, the large majority is positive.

The coefficient RE for the full sample is positive and statistically significant. More precisely, buyers who purchase their homes through real estate brokers pay on average $1.3 \%$ more for their homes. To account for heterogeneity across the full sample, we then estimate regressions on subsamples. We estimated the selling-price equation for each city. The RE coefficient was positively significant for the cities Lille-Roubaix-Tourcoing (4.2\%), Marseille (3.2\%), Toulouse $(2.5 \%)$, and Lyon $(2.4 \%)$, whereas for Nantes $(-3 \%)$ it was negative. These results are interesting because they indicate that real estate agents do not behave the same way nationwide. The Probit estimates revealed that in Lille-Roubaix-Tourcoing buyers and sellers were less likely to seek the assistance of a broker. This could be due to the fact that buyers in this area are aware of the fact that real estate brokers inflate prices and therefore are reluctant 
to seek their assistance. Moreover, the coefficients for Toulouse and half of the districts of Lyon in the Probit equation even though not significant were also negative. This was not true though for Marseille as we showed that apartments in some districts had more probability of being sold by real estate agents. The Probit coefficient for Nantes was positive but not at all significant.

We estimate separate regressions for houses from one to six rooms. It appears that real estate agent increase the prices of one and two rooms apartment by respectively $3.4 \%$ and $1.9 \%$. The impact of brokers on the other subsambles was not significant. This result is not surprising as the demand for small accommodations is large and constantly increasing due to demographic reasons. Indeed, these categories of houses are very demanded by retired and young couples, singles (single persons represent $60 \%$ of home buyers) and real estate investors' in particular because of the Robien law. As the demand for these types of properties often exceeds offer, they usually sell really fast. Therefore, real estate professionals have no trouble finding buyers who are willing to pay more for these kinds of houses.

Results for the construction period indicate that real estate agents increase the prices of houses built during the first four periods, especially the first one which corresponds to very old constructions. Interestingly, the RE coefficient is negative and significant for the subsample G of houses built between 1992 and 1999 and even though not significant, the coefficient for the subsample of new houses is also negative. The Probit estimates revealed that those two categories of buildings had a lower probability of being sold by real estate agents. But when they are sold by brokers they sell for less. This could be a result of distressed situation. Indeed, owners who sale their homes less than 13 years after buying it may face financial problems. In such a situation, sellers may be more inclined to sell cheaply and to seek the assistance of brokers in order to accelerate the selling process. Moreover, the Robien law which was passed in 2003 to boost the constructions of new accommodations gave rise to 
investment packages including credit facilities and financial insurances hooked up with the purchase of apartments not yet constructed. Buyers who buy off-plan and thus through a real estate developer usually obtain a discount. The estimates reveal that buyers who purchase through brokers get a better deal for their homes but this price advantage may be washed out by the broker commission. Sellers of old apartments will obtain a higher price for their homes by engaging a broker. This could be due to the fact that brokers have more information on prospective buyers than owners do and therefore they can better market old apartments. Nevertheless, the construction period may capture other hedonic characteristics which are not controlled for.

We then divide the data according to the age of individuals and estimate the regressions for each subsample. Real estate agents have a positive impact on prices paid by buyers who are between thirty and forty nine years old. Buyers in their forties pay, on average, $3.65 \%$ more for their homes when purchasing with the help of brokers whereas buyers in their thirties pay $1.76 \%$ more. This could be due to the fact that these categories of buyers may be first time buyers and therefore lack experience and knowledge of the real estate market. The coefficients for the other age categories of buyers are not significant. Concerning the seller's age, real estate broker obtains higher selling price for their clients aged between forty and sixty nine. The increase is about $2.8 \%$ for the first two categories and $2.4 \%$ for the last one. Surprisingly they manage to increase by $4.7 \%$ the prices of homes sold by individuals over eighty years of age which may result from a confidence effect. Indeed, this could be ascribed to the fact that elderly persons have lived in their neighbourhood for a long time and may know the real estate agent closest to his house. It appears that young buyers spend more for their houses when working with a broker whereas older sellers benefit from engaging a broker. 
We next examine the impact of real estate agents on the socio-occupational activities of buyers and sellers. Real estate brokers have a positive impact on prices paid by buyers from the categories intermediate-grade occupations and other persons without occupational activity with an increase of respectively $1.9 \%$ and $8.85 \%$. The probit estimation showed that people in the latter category where more likely to work with a broker and, when they do use a broker they pay much more for their homes with equal hedonic surface. We assumed that people buying houses from this category were wealthy and had supposedly high opportunity costs. Therefore to avoid the annoyance of searching a house for a long time and negotiating with the seller, they heavily rely on the real estate agent. Brokers may take advantage of this type of client by raising the price of the houses in order to earn a higher money commission. Clerical $(2.9 \%)$ and manual $(5.5 \%)$ workers obtain higher prices for their homes by selling through a broker. Note that the coefficients for the RE variable in all the socio-occupational subsamples are positives with the exception of buyers falling into the managers and highergrade occupations category.

Real estate brokers do not appear to discriminate between matrimonial status and gender as most RE coefficients are not significant. However, they seem to increase the prices of homes both bought and sold by single men. Brokers also statistically manage to sell widows' homes for higher prices.

\section{Conclusion}

The purpose of this study has been to empirically assess whether and to what extent real estate agents affect the sale price of French residential properties. Results were obtained using 10,610 residential apartment transactions from twelve cities in France dispersed nationwide and registered in 2005. Prices are gross prices, that is without the broker's fee. The estimates suggest that real estate brokers have a positive effect on housing price. In line with the article 
of Zietz and Newsome (2002), we find that the impact of brokers varies by property size. Statistically significant positive effects were found for one and two room apartments. The influence of brokers also varies according to the level of experience of buyers and sellers measured by age. Sellers above forty years of age appeared to benefit from the services of real estate agents by obtaining higher prices for their homes. While buyers, between thirty and fifty years old, seemed to pay the tribute of their unawareness of the real estate market. Another major finding is that real estate agents have heterogeneous behaviors depending on the city location. The estimates revealed that brokers did not affect prices in all the cities considered and in the cities they did have influence, the level was not homogenous. Furthermore, we found one city in which brokers statistically decrease housing prices.

Brokers usually claim that owners who sell their house without the assistance of brokers tend to demand higher prices for their good. Therefore, according to the real estate brokerage industry, buyers benefit from broker intermediation through lower housing prices. Our results do not confirm the marketing argument of brokers. Indeed, we found evidence that brokers increase the prices of houses they sell. In some cases, they do sell houses for lower prices but these prices do not include commission. The price advantage obtained by buyers could be washed out by the broker's commission.

The answer to the question, to whom real estate brokers benefit the most, is obviously not the buyers. Although, brokers give valuable information and as it has been proved in earlier studies they manage to reduce search time of clients, buyers pay twice the services of brokers through commission and price.

The real estate brokerage industry in the United States, for example, contrary to France offers a complete service to clients. Indeed, American brokers who are involved in the $86 \%{ }^{7}$ of real estate transactions $(60 \%$ in France), do not only sell houses, they offer turnkey solutions which can go from the inscription of children in the new school up to the administrative tasks

\footnotetext{
${ }^{7}$ Baker (2007)
} 
linked with the house moving. Offering a large range of services, promulgating strict rules of business ethics, ensuring compliance with regard to these rules, and harmonizing commissions by counting on the volume rather than the search for the highest price may be a solution to the French real estate brokerage industry problem.

This paper examined the impact of real estate brokers on housing prices. It would be interesting, for further research, to study the effect of notaries on housing prices when they serve as intermediary in the transactions. As notaries register all real estate transactions, they have an informational advantage on brokers which could lead them to act differently. 


\section{References}

Bajtelsmit, V. L. and E. Worzala, "Adversarial Brokerage in Residential Real Estate Transactions: The Impact of Separate Buyer Representation", Journal of Real Estate Research, 1997, 14:1/2, 65-74.

Baker, D., "Ethics and Lobbying: The Case of Real Estate Brokerage", Journal of Business Ethics, 2007, online.

Benjamin, J. D. and P. T. Chinloy, "Pricing, Exposure and Residential Listing Strategies", Journal of Real Estate Research, 2000, 20:1/2, 61-74.

Benjamin, J. D., G. D. Jud, and G. S. Sirmans, "Real Estate Brokerage and the Housing Market: An Annotated Bibliography", Journal of Real Estate Research, 2000, 20:1/2, 217278.

Benjamin, J. D., G. D. Jud, and G. S. Sirmans, "What Do We Know About Real Estate Brokerage?", Journal of Real Estate Research, 2000, 20:1/2, 5-30.

Black, R. T. and H. O. Nourse, “The Effect of Different Brokerage Modes on Closing Costs and House Prices”, Journal of Real Estate Research, 1995, 10:1, 87-98.

Elder, H. W., L. V. Zumpano, and E. A.Baryla, "Buyer Brokers: Do They Make a Difference? Their Influence on Selling Price and Search Duration", Real Estate Economics, 2000, 28:2, 337-62. 
Evans, R. D. and P. T. Kolbe, “Homeowners' Repeat-Sale Gains, Dual Agency and Repeated Use of the Same Agent”, Journal of Real Estate Research, 2005, 27:3, 267-292.

Jud, G. D., "Real Estate Brokers and the Market for Residential Housing", American Real Estate and Urban Economics Association Journal, 1983, 11:1, 69-82

Jud, G. D. and J. Frew, "Real Estate Brokers, Housing Prices, and the Demand for Housing”, Urban Studies, 1986, 23:1, 21-31.

Simonsohn, U., and G. Loewenstein, "Mistake \#37: The Effect of Previously Encountered Prices on Current Housing Demand", The Economic Journal, 2006, 116, 175-199.

Zietz J., and B. Newsome, “A Note on Buyer's Agent Commission and Sale Price”, Journal of Real Estate Research, 2001, 21:3, 245-53.

Zietz J., and B. Newsome, "Agency Representation and the Sale Price of Houses", Journal of Real Estate Research, 2002, 24:2, 165-91.

Zumpano, L. V., H. W. Elder, and E. A.Baryla, "Buying a House and the Decision to Use a Real Estate Broker", Journal of Real Estate Finance and Economics, 1996, 13, 169-181. 


\section{Annex 1 | Month of Closing}

Table 6 |Displays the coefficients of the month in which the closing of sale occurred for the full sample, Lyon, and Toulouse. The curves are plotted in Graph1.

\begin{tabular}{|c|c|c|c|c|c|c|c|c|c|}
\hline \multirow[b]{2}{*}{ Variable } & \multicolumn{3}{|c|}{ Full sample } & \multicolumn{3}{|c|}{ Lyon } & \multicolumn{3}{|c|}{ Toulouse } \\
\hline & Coefficient & Std Error & P-Value & Coefficient & Std Error & P-Value & Coefficient & Std Error & P-Value \\
\hline February & -13.49 & 25.11 & 0.5911 & -36.00 & 56.96 & 0.5275 & 70.87 & 70.31 & 0.3137 \\
\hline March & 52.39 & 24.85 & 0.035 & 46.07 & 53.12 & 0.3858 & 95.59 & 71.44 & 0.1811 \\
\hline April & 61.76 & 24.41 & 0.0114 & 115.89 & 53.06 & 0.0291 & 80.43 & 67.87 & 0.2361 \\
\hline Mai & 138.71 & 24.28 & $<0.0001$ & 170.26 & 52.82 & 0.0013 & 195.22 & 68.11 & 0.0042 \\
\hline June & 181.39 & 22.87 & $<0.0001$ & 209.68 & 48.10 & $<0.0001$ & 184.12 & 65.94 & 0.0053 \\
\hline July & 206.62 & 22.83 & $<0.0001$ & 192.31 & 47.73 & $<0.0001$ & 249.67 & 65.42 & $<0.0001$ \\
\hline August & 223.44 & 24.05 & $<0.0001$ & 253.11 & 53.76 & $<0.0001$ & 295.25 & 71.79 & $<0.0001$ \\
\hline September & 290.04 & 22.51 & $<0.0001$ & 242.27 & 47.43 & $<0.0001$ & 373.58 & 64.35 & $<0.0001$ \\
\hline October & 277.50 & 24.46 & $<0.0001$ & 184.12 & 51.85 & 0.0004 & 324.55 & 74.71 & $<0.0001$ \\
\hline November & 304.59 & 24.97 & $<0.0001$ & 223.83 & 52.60 & $<0.0001$ & 389.73 & 73.59 & $<0.0001$ \\
\hline December & 308.49 & 23.45 & $<0.0001$ & 273.76 & 49.08 & $<0.0001$ & 321.47 & 66.54 & $<0.0001$ \\
\hline
\end{tabular}

The cities of Montpellier and Nancy do not show statistically significant differences between the months of sale. The coefficients for Marseille and Strasbourg start being significant from the month of June and the one for Rennes from July at a 5\% level. The coefficients for LilleRoubaix-Tourcoing are significant from the month of July with the exception of May which is significant at a 5\% level. February is never significant and March is significant for the full sample, Bordeaux, and Nantes. In all samples an increasing trend may be distinguished.

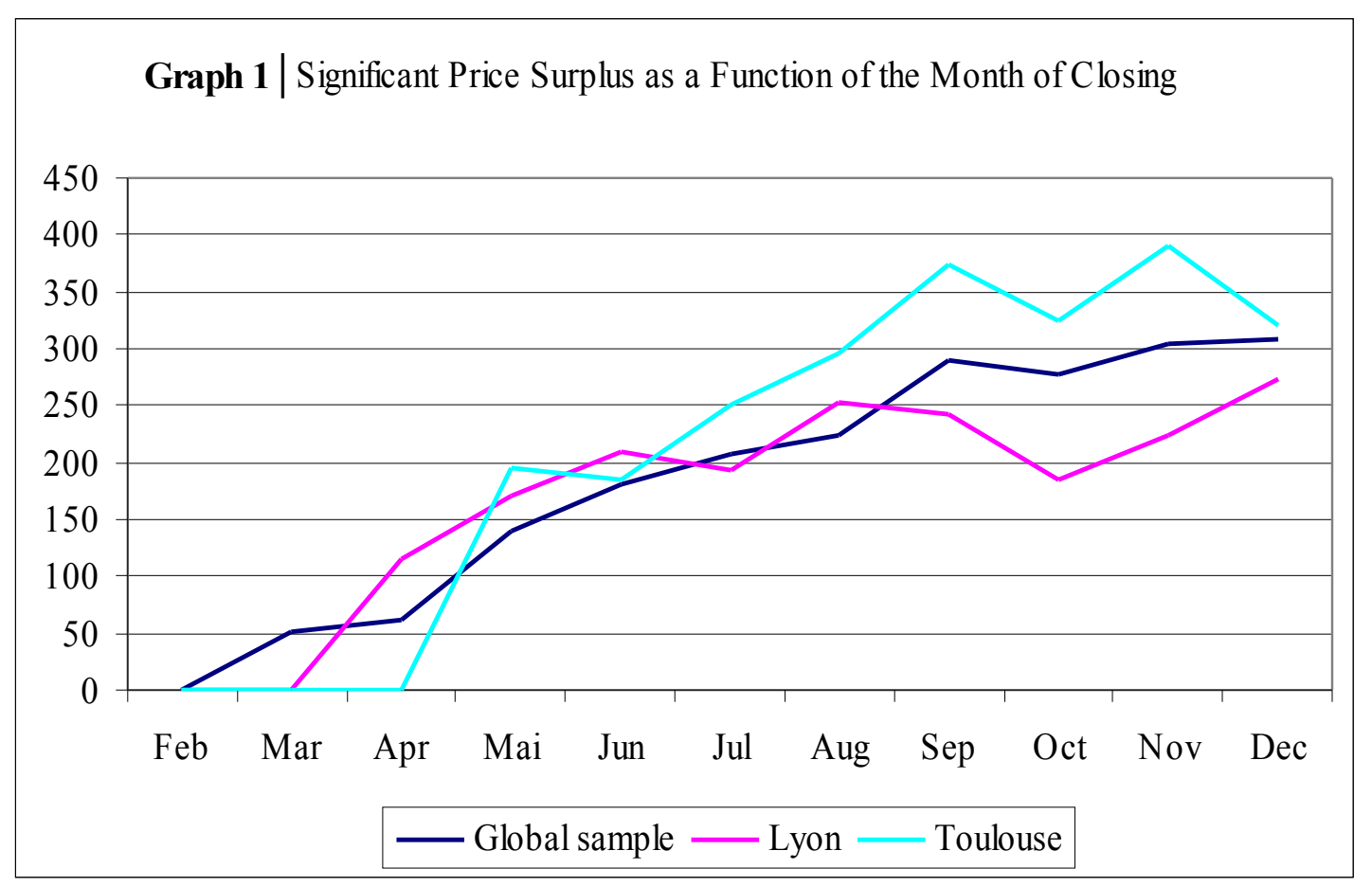




\section{Annex 2 | Chart of Marseille}

The map below represents the city of Marseille which is divided in sixteen districts. The seven first districts compose the town center.

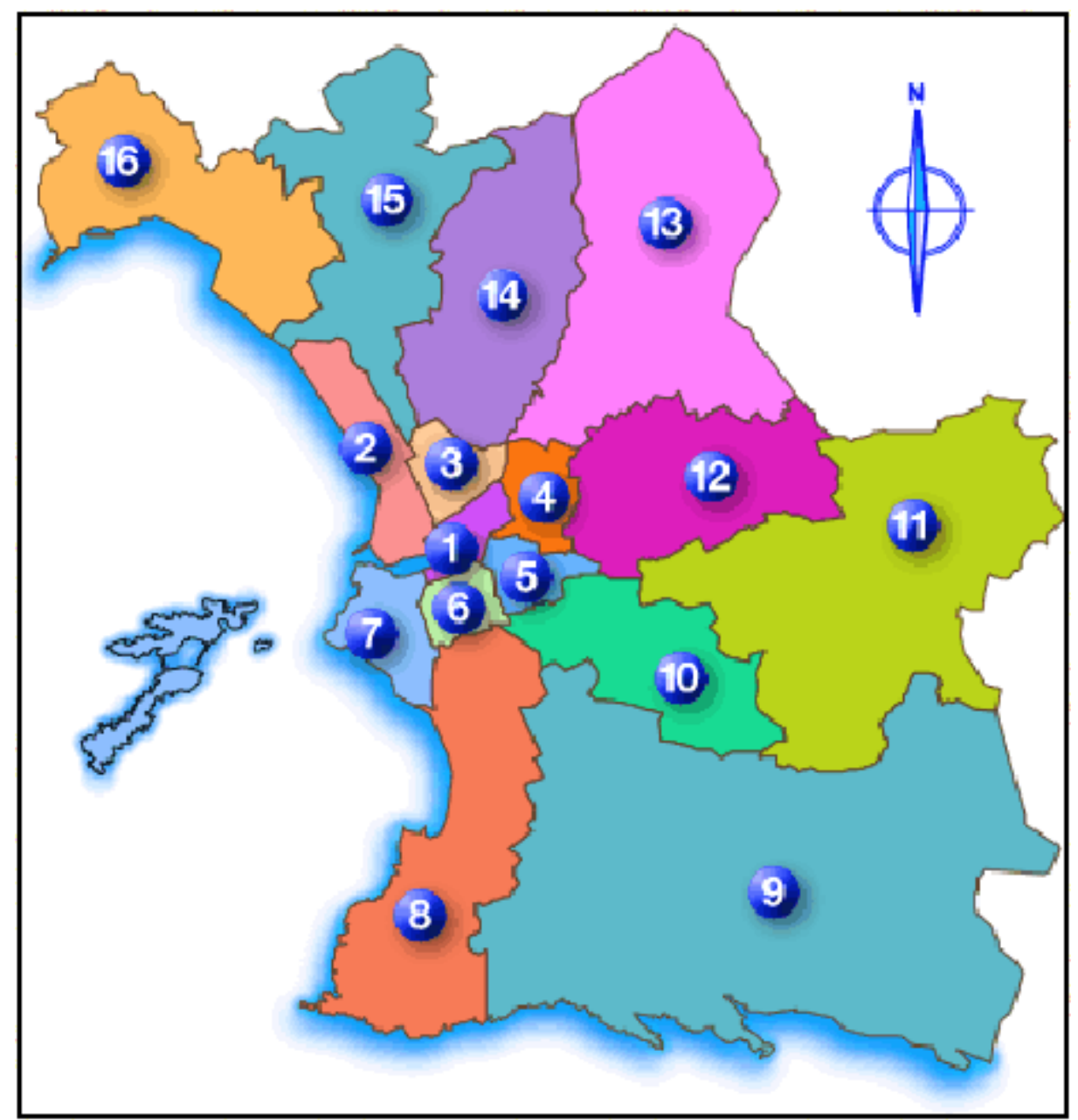

Origin: http://orthoptie.net/ 


\section{Intermediation}

Agent-assisted transaction (RE): Takes the value 1 if a real estate broker is engaged in the transaction and 0 otherwise.

\section{Hedonic characteristics}

Sale price (PM2): Price per square meters in euros paid by a buyer for a house.

City: A vector of city location variables, equalling 1 if the house is situated in that city and 0 otherwise. The cities are: Bordeaux, Lille, Lyon ( 9 urban districts), Marseille (16 urban districts + one category for unknown district), Montpellier, Nancy, Nantes, Rennes, Roubaix, Strasbourg, Toulouse, and Tourcoing. We reunited the cities of Lille, Roubaix and Tourcoing as they are very near to each other

Street type: A vector of street type variables: alley, avenue, blind alley, boulevard, crossroad, path, park, public garden, square, street, residence, road, etc.

Apartment type (St, Lo, Du, Tr): A vector of apartment type variables (standard, loft, duplex, triplex).

Rooms $(\mathrm{R} x)$ : A vector representing the number of rooms in the house: from 1 to 8 . Houses with more than eight rooms are set in the 8 and more room category.

Floor $(\mathrm{F} x)$ : A vector representing the floor number: from 0 to 9 , floors 10 to 19 are put in the same category, and the last category contains floors 20 and above.

Month of sale $(\mathrm{M} x)$ : A vector representing the month in which the closing of sale occurred.

Number of cellars in the house (Cellar)

Number of bathrooms in the house (Bath)

Construction period (A to $\mathrm{H}$ ): A vector of categorical variables representing the construction period. The categories are: <1850; 1851-1913; 1914-1947; 1948-1969; 1970-1980; 1981-1991; 1992-1999; 2000-2005.

Terrace (Terrace): An indicator variable that takes the value 1 if there is a terrace and 0 otherwise.

Balcony (Balcony): An indicator variable that takes the value 1 if there is a balcony and 0 otherwise.

Loggia (Loggia): An indicator variable that takes the value 1 if there is a loggia and 0 otherwise.

Storeroom (Storeroom): An indicator variable that takes the value 1 if there is a storeroom and 0 otherwise.

Attic (Attic): An indicator variable that takes the value 1 if there is a attic and 0 otherwise.

\section{Buyers' and sellers' characteristics}

Socio-occupational category ( $\mathrm{SOC} x$ ): A vector of categorical socio-occupational variables, equalling 1 if the occupation of the agent falls into that category, 0 otherwise. The categories are: Farmers; Artisans, shopkeepers, and employers; Managers and higher-grade occupations; Intermediate-grade occupations; Clerical workers; Manual workers; Retired persons; Other persons without occupational activity.

Matrimonial status: A vector of categorical variables that represents the matrimonial status and the gender of the person who signs the contract. The categories are: married, single, divorced, remarried, PACS contract which corresponds to a legal contract concluded between two adults of opposite sex or not in order to organize their common life (equivalent of common-law), and widowed. Each category is divided into man and woman.

Age (AGExx): A vector of categorical variables that represents the age of the agent. The categories are: 1829 years; $30-39$ years; $40-49$ years; $50-59$ years; $60-69$ years; $70-79$ years; 80 years and up.

Nationality: A vector representing different nationality: Algeria; Belgium; France; Germany; Italy; Morocco; Portugal; Spain; Tunisia; Turkey; United Kingdom; others. 
Table 2a $\mid$ Summary statistics of hedonic characteristics

The first column lists the hedonic variables. The second, third, and fourth columns give the average value or the percentage $(\%)$ of the hedonic characteristic in the broker-assisted sample, the non-broker-assisted sample, and the full sample respectively. For location, type of apartment, and construction period, the sum does not always equal 100 due to approximations. Note that transactions in the city of Lyon represent $21.4 \%$ of transactions in all three samples; this is pure coincidence. The fifth column shows the percentage of broker-assisted transactions in the full sample for each characteristic.

\begin{tabular}{|c|c|c|c|c|}
\hline & $\begin{array}{l}\text { Broker-Assisted } \\
\text { Transactions }\end{array}$ & $\begin{array}{l}\text { Non-Broker-Assisted } \\
\text { Transactions }\end{array}$ & Full Sample & $\begin{array}{l}\text { Proportion of Broker-Assisted } \\
\text { Transactions in Full Sample }\end{array}$ \\
\hline \multicolumn{5}{|l|}{ House Characteristics } \\
\hline PM2 (Purchase price) & $\begin{array}{l}2195.47 € \\
(606.34)^{*}\end{array}$ & $\begin{array}{l}2148.56 € \\
(678.21)^{*}\end{array}$ & $\begin{array}{l}2181.70 € \\
(626.37)^{*}\end{array}$ & /I \\
\hline Lyon $(\%)--ー-ー-・$ & $-\frac{-21 . \overline{4}}{-}$ & -21.4 & $--\frac{7}{21.4}-$ & $---\overline{70} . \overline{6}$ \\
\hline Marseille (\%) & 13.3 & 20.5 & 15.4 & 61.0 \\
\hline Lille/ Roubaix/Tourcoing (\%) & 7.9 & 4.9 & 7.0 & 79.5 \\
\hline Nancy (\%) & 3.2 & 3.3 & 3.2 & 69.4 \\
\hline Toulouse (\%) & 13.3 & 13.4 & 13.4 & 70.5 \\
\hline Montpellier (\%) & 3.7 & 3.5 & 3.6 & 71.8 \\
\hline Rennes (\%) & 9.2 & 7.6 & 8.7 & 74.5 \\
\hline Nantes (\%) & 12.4 & 9.6 & 11.5 & 75.7 \\
\hline Bordeaux (\%) & 7.9 & 6.5 & 7.5 & 74.6 \\
\hline Strasbourg (\%) & -7.8 & 9.3 & 8.3 & 66.8 \\
\hline Standard (\%) & 95.1 & $9 \overline{5} \overline{7}$ & $\overline{95.3}$ & 70.5 \\
\hline Loft (\%) & 0.1 & 0.1 & 0.1 & 72.7 \\
\hline Duplex (\%) & 4.7 & 3.9 & 4.4 & 74.3 \\
\hline Triplex (\%) & 0.2 & 0.3 & 0.2 & 52.4 \\
\hline $\mathrm{A}(\%)$ & 2.4 & 2.3 & 2.4 & 71.4 \\
\hline B (\%) & 6.7 & 7.1 & 6.8 & 69.5 \\
\hline $\mathrm{C}(\%)$ & 9.6 & 10.7 & 9.9 & 68.3 \\
\hline D (\%) & 23.0 & 29.1 & 24.8 & 65.5 \\
\hline E (\%) & 15.2 & 16.4 & 15.5 & 69.1 \\
\hline $\mathrm{F}(\%)$ & 14.4 & 14.6 & 14.5 & 70.3 \\
\hline G (\%) & 11.4 & 8.2 & 10.4 & 76.9 \\
\hline$\underline{H}(\%)$ & 17.4 & 11.6 & 15.7. & 78.3 \\
\hline Terrace $(\%)$ & 7.5 & 6.8 & 7.3 & 72.6 \\
\hline Balcony (\%) & 21.9 & 20.9 & 21.6 & 71.7 \\
\hline Loggia (\%) & 13.0 & 14.4 & 13.4 & 68.5 \\
\hline Storeroom (\%) & 15.6 & 16.2 & 15.8 & 69.8 \\
\hline Attic (\%) -- & 7.0 & 6.2 & 6.7 & 73.1 \\
\hline Number of rooms & 2.9 & 2.8 & $2.9^{-}$ & $\pi$ \\
\hline Floor number & 2.8 & 2.7 & 2.7 & // \\
\hline Number of cellars & 0.6 & 0.6 & 0.6 & // \\
\hline Number of bath rooms & 1.1 & 1.0 & 1.0 & 11 \\
\hline
\end{tabular}


Table 3 Probit estimates of broker use as a function of individual characteristics

\begin{tabular}{|c|c|c|c|c|c|c|}
\hline \multirow[b]{2}{*}{ Variable } & \multicolumn{3}{|c|}{ Buyer } & \multicolumn{3}{|c|}{ Seller } \\
\hline & Coefficient & Std Error & Significance level & Coefficient & Std Error & Significance level \\
\hline Intercept & -0.6339 & 0.28 & 0.0236 & // & $/ /$ & $/ /$ \\
\hline SOC2 & 0.3307 & 0.2005 & 0.0992 & 0.0219 & 0.2017 & 0.9134 \\
\hline SOC3 & 0.1747 & 0.1956 & 0.3717 & -0.0104 & 0.1981 & 0.9582 \\
\hline SOC4 & 0.2881 & 0.1956 & 0.1409 & 0.00375 & 0.1984 & 0.9849 \\
\hline SOC5 & 0.2764 & 0.1972 & 0.1611 & -0.0489 & 0.2002 & 0.8072 \\
\hline SOC6 & 0.3417 & 0.201 & 0.0891 & -0.0569 & 0.2061 & 0.7826 \\
\hline SOC7 & 0.2773 & 0.2077 & 0.1817 & 0.0625 & 0.2004 & 0.7551 \\
\hline SOC8 & 0.4066 & 0.2066 & 0.0491 & -0.0124 & 0.2058 & 0.952 \\
\hline Age 30-39 & 0.0968 & 0.0341 & 0.0046 & -0.0892 & 0.0535 & 0.0952 \\
\hline Age 40-49 & 0.0459 & 0.0417 & 0.2715 & -0.1486 & 0.0571 & 0.0093 \\
\hline Age 50-59 & 0.0171 & 0.0472 & 0.7175 & -0.1713 & 0.0573 & 0.0028 \\
\hline Age 60-69 & 0.047 & 0.0852 & 0.5817 & -0.2379 & 0.0686 & 0.0005 \\
\hline Age 70-79 & 0.0542 & 0.1113 & 0.6262 & -0.1689 & 0.0792 & 0.033 \\
\hline Age 80 and over & 0.0281 & 0.167 & 0.8663 & -0.0843 & 0.0894 & 0.3461 \\
\hline Married woman & 0.0462 & 0.0736 & 0.5305 & 0.0183 & 0.0513 & 0.7223 \\
\hline Single woman & -0.00611 & 0.0399 & 0.8783 & 0.025 & 0.045 & 0.5777 \\
\hline Single man & 0.00445 & 0.0364 & 0.9026 & 0.0605 & 0.0415 & 0.145 \\
\hline Divorced woman & -0.1177 & 0.0548 & 0.0317 & -0.0199 & 0.0532 & 0.7078 \\
\hline Divorced man & 0.1108 & 0.0637 & 0.0816 & 0.0138 & 0.0582 & 0.8132 \\
\hline Remarried woman & 0.1677 & 0.2567 & 0.5135 & -0.0672 & 0.1731 & 0.6978 \\
\hline Remarried man & 0.0686 & 0.1516 & 0.651 & 0.0696 & 0.0956 & 0.4665 \\
\hline PACS woman & -0.5495 & 0.3113 & 0.0775 & -0.4477 & 0.3678 & 0.2236 \\
\hline PACS man & 0.0799 & 0.1429 & 0.5758 & 0.1114 & 0.2603 & 0.6685 \\
\hline Widow & -0.1087 & 0.0902 & 0.228 & -0.0436 & 0.0554 & 0.4314 \\
\hline Widower & -0.1701 & 0.1966 & 0.3869 & 0.1326 & 0.1011 & 0.1896 \\
\hline Algeria & 0.0661 & 0.2158 & 0.7596 & 0.2697 & 0.2499 & 0.2805 \\
\hline Belgium & -0.4489 & 0.4468 & 0.315 & 0.4537 & 0.8907 & 0.6105 \\
\hline Germany & -0.1387 & 0.3486 & 0.6907 & 0.0507 & 0.3775 & 0.8932 \\
\hline Italy & -0.00695 & 0.2629 & 0.9789 & 0.021 & 0.2847 & 0.9413 \\
\hline Morocco & 0.1092 & 0.2532 & 0.6662 & 0.604 & 0.3804 & 0.1124 \\
\hline Portugal & -0.2245 & 0.2843 & 0.4298 & -0.1644 & 0.3119 & 0.5982 \\
\hline Spain & -0.7049 & 0.4122 & 0.0872 & -0.4603 & 0.323 & 0.1541 \\
\hline Tunisia & 0.4457 & 0.3384 & 0.1878 & -4.236 & 35.7926 & 0.9058 \\
\hline Turkey & 0.3511 & 0.2982 & 0.2391 & 0.5669 & 0.3764 & 0.1321 \\
\hline United Kingdom & -1.0177 & 0.3523 & 0.0039 & -0.3726 & 0.3247 & 0.2511 \\
\hline Other nationality & -0.1097 & 0.1443 & 0.4471 & 0.2682 & 0.2129 & 0.2079 \\
\hline Log-likelihood (70) & 126.5 & & $<.0001$ & & & \\
\hline
\end{tabular}


Table 4 Probit estimates of broker use as a function of hedonic characteristics

\begin{tabular}{|c|c|c|c|}
\hline Variable & Coefficient & Std error & Significance level \\
\hline Intercept & 0.0591 & 0.246 & 0.8102 \\
\hline B & 0.00675 & 0.0951 & 0.9434 \\
\hline $\mathrm{C}$ & 0.0452 & 0.0919 & 0.6226 \\
\hline D & 0.1126 & 0.0883 & 0.2022 \\
\hline E & 0.037 & 0.0909 & 0.6837 \\
\hline $\mathrm{F}$ & 0.0257 & 0.091 & 0.7779 \\
\hline G & -0.1621 & 0.0944 & 0.086 \\
\hline $\mathbf{H}$ & -0.2025 & 0.0897 & 0.024 \\
\hline DU & 0.0311 & 0.0635 & 0.6245 \\
\hline LO & -0.0643 & 0.4155 & 0.8771 \\
\hline TR & 0.5314 & 0.28 & 0.0577 \\
\hline $\mathrm{R} 2$ & 0.0212 & 0.0415 & 0.609 \\
\hline R3 & -0.0236 & 0.0423 & 0.5763 \\
\hline R4 & -0.0285 & 0.0455 & 0.5304 \\
\hline R5 & -0.1082 & 0.0622 & 0.082 \\
\hline R6 & -0.1506 & 0.1151 & 0.1908 \\
\hline R7 & -0.2095 & 0.2333 & 0.369 \\
\hline $\mathrm{R} 8$ & -3.9097 & 38.056 & 0.9182 \\
\hline Lyon district 2 & 0.1035 & 0.1528 & 0.4981 \\
\hline Lyon district 3 & -0.00049 & 0.1158 & 0.9966 \\
\hline Lyon district 4 & 0.0811 & 0.1341 & 0.5451 \\
\hline Lyon district 5 & 0.0215 & 0.1281 & 0.8668 \\
\hline Lyon district 6 & 0.0486 & 0.1254 & 0.6984 \\
\hline Lyon district 7 & -0.1409 & 0.1209 & 0.2437 \\
\hline Lyon district 8 & -0.0628 & 0.133 & 0.6367 \\
\hline Lyon district 9 & -0.0828 & 0.1366 & 0.5443 \\
\hline Marseille unknown district & 0.1037 & 0.1469 & 0.4801 \\
\hline Marseille district 1 & 0.0406 & 0.1613 & 0.8012 \\
\hline Marseille district 2 & 0.2037 & 0.2198 & 0.3541 \\
\hline Marseille district 3 & 0.1572 & 0.169 & 0.3523 \\
\hline Marseille district 4 & 0.2535 & 0.1499 & 0.0908 \\
\hline Marseille district 5 & 0.1774 & 0.16 & 0.2674 \\
\hline Marseille district 6 & 0.2102 & 0.1511 & 0.164 \\
\hline Marseille district 7 & -0.0441 & 0.1658 & 0.7901 \\
\hline Marseille district 8 & 0.2443 & 0.1404 & 0.0818 \\
\hline Marseille district 9 & 0.1336 & 0.1454 & 0.3581 \\
\hline Marseille district 10 & 0.0597 & 0.1821 & 0.7431 \\
\hline Marseille district 11 & 0.2353 & 0.2147 & 0.2729 \\
\hline Marseille district 12 & 0.2036 & 0.1672 & 0.2233 \\
\hline Marseille district 13 & 0.0122 & 0.1734 & 0.944 \\
\hline Marseille district 14 & 0.6045 & 0.1886 & 0.0014 \\
\hline Marseille district 15 & 0.5167 & 0.1707 & 0.0025 \\
\hline Marseille district 16 & -0.0761 & 0.3532 & 0.8295 \\
\hline Lille & -0.2079 & 0.1066 & 0.0646 \\
\hline Roubaix & -0.2115 & 0.11 & 0.2385 \\
\hline Tourcoing & -0.4133 & 0.1212 & 0.0326 \\
\hline Bordeaux & -0.153 & 0.1933 & 0.1644 \\
\hline Montpellier & -0.0568 & 0.1191 & 0.639 \\
\hline Nancy & 0.1304 & 0.1082 & 0.2733 \\
\hline Nantes & 0.0412 & 0.1795 & 0.6934 \\
\hline Rennes & 0.0397 & 0.1125 & 0.7136 \\
\hline Strasbourg & 0.0928 & 0.1086 & 0.393 \\
\hline Toulouse & -0.0483 & 0.1045 & 0.6502 \\
\hline Log-likelihood (110) & 262.8 & & $<.0001$ \\
\hline
\end{tabular}

Omitted category variables are: period of construction A, Standard apartment, one-room apartment, and Lyon district 1. We do not report all the variables only the ones of major interest. 
Table 5 | House price estimates

The dependent variable is PM2. The values of the coefficient RE for the full and subsambles are presented.

The functional form of the equation for each sample is: $\mathrm{PM} 2=f$ (hedonic characteristics, $\mathrm{RE}$ ).

\begin{tabular}{|c|c|c|c|c|}
\hline Sample & Coefficient & Std Error & Significance level & Average PM2 \\
\hline Full sample & 28.04 & 10.72 & 0.0089 & 2176.38 \\
\hline \multicolumn{5}{|l|}{ Cities } \\
\hline Bordeaux & 9.53 & 37.35 & 0.7987 & 2059.12 \\
\hline LRT & 85.00 & 40.33 & 0.0354 & 2034.19 \\
\hline Lyon & 56.74 & 21.89 & 0.0096 & 2381.66 \\
\hline Marseille & 74.47 & 29.06 & 0.0105 & 2328.93 \\
\hline Montpellier & 54.96 & 74.81 & 0.463 & 2237.09 \\
\hline Nancy & 12.39 & 46.87 & 0.7917 & 1572.68 \\
\hline Nantes & -65.31 & 31.18 & 0.0364 & 2175.39 \\
\hline Rennes & -41.42 & 33.33 & 0.2143 & 2210.90 \\
\hline Strasbourg & -13.00 & 34.43 & 0.7058 & 1888.58 \\
\hline Toulouse & 52.11 & 30.86 & 0.0916 & 2106.68 \\
\hline \multicolumn{5}{|l|}{ Number of rooms } \\
\hline R1 & 80.44 & 31.90 & 0.0118 & 2345.23 \\
\hline $\mathbf{R 2}$ & 41.79 & 21.51 & 0.0521 & 2203.50 \\
\hline R3 & -11.12 & 18.83 & 0.555 & 2127.26 \\
\hline R4 & 2.59 & 21.03 & 0.9021 & 2071.00 \\
\hline R5 & 25.82 & 41.10 & 0.5301 & 2172.06 \\
\hline R6 & -21.26 & 110.59 & 0.8479 & 2378.01 \\
\hline \multicolumn{5}{|l|}{ Construction code } \\
\hline $\mathbf{A}$ & 189.58 & 96.60 & 0.0511 & 2449.91 \\
\hline B & 88.87 & 44.16 & 0.0446 & 2293.41 \\
\hline $\mathbf{C}$ & 97.03 & 37.59 & 0.01 & 2180.06 \\
\hline D & 40.00 & 19.15 & 0.0368 & 2006.50 \\
\hline $\mathrm{E}$ & 0.50 & 24.68 & 0.984 & 2053.83 \\
\hline $\mathrm{F}$ & 7.47 & 25.52 & 0.7696 & 2236.64 \\
\hline G & -64.83 & 36.00 & 0.072 & 2602.52 \\
\hline $\mathrm{H}$ & -21.04 & 32.24 & 0.5142 & 2134.29 \\
\hline \multicolumn{5}{|l|}{ Buyer age } \\
\hline Age 18-29 & -9.64 & 18.75 & 0.6074 & 2093.85 \\
\hline Age 30-39 & 37.66 & 19.78 & 0.057 & 2142.36 \\
\hline Age 40-49 & 80.40 & 26.29 & 0.0023 & 2204.35 \\
\hline Age 50-59 & 24.16 & 29.80 & 0.4177 & 2250.93 \\
\hline Age $60-69$ & -8.38 & 47.76 & 0.8608 & 2323.93 \\
\hline Age 70-79 & -49.52 & 75.34 & 0.5117 & 2426.58 \\
\hline Age 80 and over & -456.00 & 618.21 & 0.4847 & 2229.61 \\
\hline \multicolumn{5}{|l|}{ Seller age } \\
\hline Age 18-29 & 9.65 & 36.83 & 0.7934 & 2267.72 \\
\hline Age 30-39 & 9.49 & 20.44 & 0.6426 & 2284.74 \\
\hline Age 40-49 & 62.90 & 26.75 & 0.0188 & 2197.94 \\
\hline Age 50-59 & 61.19 & 24.53 & 0.0127 & 2165.95 \\
\hline Age 60-69 & 51.24 & 27.33 & 0.061 & 2122.05 \\
\hline Age 70-79 & -27.61 & 38.22 & 0.4702 & 2070.06 \\
\hline Age 80 and over & 90.77 & 50.16 & 0.0709 & 1929.19 \\
\hline
\end{tabular}


Table 5 | House price estimates (continued)

The dependent variable is PM2. The values of the coefficient RE for the full and subsambles are presented.

The functional form of the equation for each sample is: $\mathrm{PM} 2=f$ (hedonic characteristics, RE).

\begin{tabular}{|c|c|c|c|c|}
\hline Sample & Coefficient & Std Error & Significance level & Average PM2 \\
\hline \multicolumn{5}{|c|}{ Buyer socio-occupational category } \\
\hline SOC2 & 55.97 & 49.95 & 0.263 & 2128.78 \\
\hline $\mathrm{SOC} 3$ & -28.07 & 21.71 & 0.1962 & 2330.19 \\
\hline SOC4 & 40.39 & 17.78 & 0.0232 & 2126.13 \\
\hline SOC5 & 24.84 & 25.77 & 0.3354 & 2040.37 \\
\hline SOC6 & 23.35 & 39.06 & 0.5502 & 1854.74 \\
\hline SOC7 & 24.87 & 36.67 & 0.4978 & 2310.12 \\
\hline SOC8 & 196.84 & 71.81 & 0.0065 & 2224.88 \\
\hline \multicolumn{5}{|c|}{ Seller socio-occupational category } \\
\hline $\mathrm{SOC} 2$ & 8.79 & 49.65 & 0.8595 & 2250.89 \\
\hline $\mathrm{SOC} 3$ & 22.38 & 23.87 & 0.3484 & 2330.64 \\
\hline SOC4 & 25.13 & 20.35 & 0.217 & 2207.24 \\
\hline SOC5 & 62.23 & 29.77 & 0.0368 & 2139.02 \\
\hline SOC6 & 107.54 & 52.87 & 0.0427 & 1970.84 \\
\hline SOC7 & 29.30 & 21.07 & 0.1643 & 2064.06 \\
\hline SOC8 & 34.39 & 59.28 & 0.5621 & 2119.93 \\
\hline \multicolumn{5}{|c|}{ Buyer matrimonial status } \\
\hline Single woman & 8.28 & 24.72 & 0.7378 & 2160.36 \\
\hline Single man & 56.93 & 19.78 & 0.004 & 2108.32 \\
\hline Married woman & 92.30 & 71.03 & 0.195 & 2207.05 \\
\hline Married man & -7.38 & 18.97 & 0.6971 & 2235.07 \\
\hline Remarried man & -9061.37 & 4441.91 & 0.2902 & 2271.15 \\
\hline Widow & 105.28 & 81.65 & 0.199 & 2257.60 \\
\hline Widower & -561.42 & 519.41 & 0.3156 & 2274.16 \\
\hline \multicolumn{5}{|c|}{$\underline{\text { Seller matrimonial status }}$} \\
\hline Single woman & 28.36 & 37.21 & 0.4462 & 2200.47 \\
\hline Single man & 69.91 & 28.45 & 0.0141 & 2232.64 \\
\hline Married woman & 43.41 & 40.85 & 0.2883 & 2123.92 \\
\hline Married man & 10.11 & 16.05 & 0.5285 & 2201.02 \\
\hline Remarried man & -57.32 & 114.55 & 0.6179 & 2168.54 \\
\hline Widow & 89.65 & 40.96 & 0.0289 & 2021.67 \\
\hline Widower & 71.02 & 104.12 & 0.497 & 1923.88 \\
\hline
\end{tabular}

